\title{
Digital Mapping of Cultural Heritage as a Learning Source for Local History in Indonesia
}

\author{
Jumardi* and Soeprijanto Diana Nomida Musnir
}

\begin{abstract}
Department of education technology, post graduate, Jakarta State University, Jakarta, Indonesia *Corresponding author. Email: jumardi_7127140043@mhs.unj.ac.id
\end{abstract}

\begin{abstract}
Buildings or historical objects that are scattered throughout Indonesia, especially DKI Jakarta can be used as a source of learning local history in universities and even secondary schools in Indonesia. Through Law Number 11 of 2010 concerning Cultural Heritage to be used for the interests of religion, social, education, science, technology, culture and tourism. The purpose of this study is to improve local history learning and improve digital literacy culture so that it has an impact on regional tourism promotion. This study uses a model development that will use ArcGIS 9.3.1. This research will only convey the initial data on cultural heritage which will be used as digital mapping. The determination of cultural heritage was obtained by conducting a survey of 50 students in DKI Jakarta.
\end{abstract}

Keywords: Mapping and Learning Resources of Local History.

\section{INTRODUCTION}

Cultural heritage reflects the history of a nation and an important part of a nation [1]. Article 1 paragraph (1) Law no. 11/2010 concerning cultural heritage explains that cultural heritage as cultural heritage is material in the form of cultural heritage objects, cultural heritage buildings, cultural heritage structures, cultural heritage sites, and cultural heritage areas on land and / or in water that need to be preserved because of its value. important for history, science, education, religion and / or culture through a process of determination. Located throughout the geographical area of Indonesia, which needs to be preserved for the younger generation as a national heritage [2].

Local history is an inseparable part of Indonesia's national history. In the history of Indonesia, the role of society, individuals, communities, and institutions in a particular area has become the study of local history. This will help to appreciate history [3]. The study of Heritage in local context values History as a learning living source, facilitates the understanding of historical concepts and helps to understand the world in which we live, contributing to the multiple understanding of history and to the building of the three pillars of history education: History - Memory - Identity. The Local history gives the students sensitivity level of the history because the students will better understand the objects that occur in their environment. Besides, the local history has the history of local wisdom values that exist in society [4]. The values of local wisdom can be a matterial for the formation of the students' character.

The importance of local history in learning for students needs to be done in the development of a learning model in the classroom. One of them is by utilizing information technology. Technology makes it easy to map local historical sources throughout Indonesia, especially DKI Jakarta. Local history learning invites students to be able to explore local historical sources that exist in their area as a balance between local and national or regional history. The material of local history cannot be separated from the context of national history and must not be too separatist or ethnocentric, which will cause disintegration of the nation and endanger the unity of the nation [5].

This study aims to utilize cultural heritage as part of learning local history in Indonesia, especially DKI Jakarta. All cultural heritage in the DKI Jakarta area, both objects and non-objects, are recorded to be compiled in local historical materials. This study uses a model development that will use ArcGIS 9.3.1. then the preliminary data collection of cultural heritage in DKI Jakarta and Jabodetabek areas will be carried out which will convey information and identification of cultural heritage in the 
DKI Jakarta area which will be used as a source of learning local history.

\section{LOCAL HISTORY LEARNING}

In several countries, local history learning is carried out using various learning models. Turkey, learning local history using Geography, culture and field studies approach [6]. Portugal local history learning using technology such as mobile devices with dereferencing software [7]. Norwegian local history learning using the project "Local History around the World: International Internet Inventory". Indonesia, local history learning is only carried out in classes with a varied lecture model.

\section{RESULTS AND DISCUSSION}

Mapping of cultural heritage is something that must be done to increase the learning of local history. Cultural heritage, both objects and non-objects, is a legacy that must be known by every generation to improve attitudes and morality and national identity [8]. Mapping can not only be used for learning local history, but can also be used for tourists in search of locations and information about cultural heritage [9].

Table 1. Mapping of the Cultural Heritage of DKI Jakarta.

\begin{tabular}{|c|c|c|}
\hline No. & Cultural Heritage Theme & Location \\
\hline 1 & The Water Warehouse 1922 & $\begin{array}{l}\text { DKI Jakarta, } \\
\text { East Jakarta }\end{array}$ \\
\hline 2 & Jatinegara (Meester Cornelis). & $\begin{array}{l}\text { DKI Jakarta, } \\
\text { East Jakarta }\end{array}$ \\
\hline 3 & Historical market in Jakarta. & DKI Jakarta \\
\hline 4 & Jakarta Old Town Area. & $\begin{array}{l}\text { DKI Jakarta, } \\
\text { West Jakarta }\end{array}$ \\
\hline 5 & Priok Peninsula area. & $\begin{array}{l}\text { DKI Jakarta, } \\
\text { North Jakarta }\end{array}$ \\
\hline 6 & $\begin{array}{l}\text { Historical station in DKI } \\
\text { Jakarta }\end{array}$ & DKI Jakarta \\
\hline 7 & Xylophone Kromong. & $\begin{array}{l}\text { DKI Jakarta, } \\
\text { Central Jakarta }\end{array}$ \\
\hline 8 & Jakarta's cultural icon & DKI Jakarta \\
\hline 9 & $\begin{array}{l}\text { Kyai Noor Alie, his role and } \\
\text { influence }\end{array}$ & $\begin{array}{l}\text { DKI Jakarta, } \\
\text { East Jakarta }\end{array}$ \\
\hline 10 & $\begin{array}{l}\text { The struggle mosque in } \\
\text { Jakarta. }\end{array}$ & DKI Jakarta \\
\hline 11 & Patented Site & Serang, Banten \\
\hline 12 & Pamarayan Dam & Banten \\
\hline 13 & Raden Saleh Hospital & $\begin{array}{l}\text { DKI Jakarta, } \\
\text { Central Jakarta }\end{array}$ \\
\hline 14 & Rangkas Bitung Station & Banten \\
\hline
\end{tabular}

Table 2. Mapping of Street Names based on National / Local Hero Names

\begin{tabular}{|c|c|c|}
\hline No. & Cultural Heritage Theme & Location \\
\hline 1 & HR Rasuna Said & $\begin{array}{l}\text { DKI Jakarta, } \\
\text { South Jakarta }\end{array}$ \\
\hline 2 & Sudirman & DKI Jakarta \\
\hline 3 & M Saidi Raya & $\begin{array}{l}\text { DKI Jakarta, } \\
\text { South Jakarta }\end{array}$ \\
\hline 4 & MHT & DKI Jakarta \\
\hline 5 & TB Simatupang & DKI Jakarta \\
\hline 6 & Daan Mogot & $\begin{array}{l}\text { DKI Jakarta, } \\
\text { West Jakarta }\end{array}$ \\
\hline 7 & M Yamin & DKI Jakarta \\
\hline 8 & Djokosoetono & $\begin{array}{l}\text { DKI Jakarta, } \\
\text { South Jakarta }\end{array}$ \\
\hline 9 & Sutan Syahrir & $\begin{array}{l}\text { DKI Jakarta, } \\
\text { South Jakarta }\end{array}$ \\
\hline 10 & Soeprapto & $\begin{array}{l}\text { DKI Jakarta, } \\
\text { Central Jakarta }\end{array}$ \\
\hline
\end{tabular}

Table 3. Mapping of Historical Mosques in DKI Jakarta

\begin{tabular}{|c|c|c|}
\hline No. & Cultural Heritage Theme & Location \\
\hline 1 & $\begin{array}{l}\text { Masjid Jami AL-Atiq } \\
\text { Kampung Melayu Besar }\end{array}$ & $\begin{array}{l}\text { DKI Jakarta, } \\
\text { South Jakarta }\end{array}$ \\
\hline 2 & $\begin{array}{l}\text { Jami An-Nawier Pekojan } \\
\text { Mosque }\end{array}$ & $\begin{array}{l}\text { DKI Jakarta, } \\
\text { West Jakarta }\end{array}$ \\
\hline 3 & $\begin{array}{l}\text { AL-Anwar Muara Angke } \\
\text { Mosque }\end{array}$ & $\begin{array}{l}\text { DKI Jakarta, } \\
\text { West Jakarta }\end{array}$ \\
\hline 4 & Sunda Kelapa Grand Mosque & $\begin{array}{l}\text { DKI Jakarta, } \\
\text { Central Jakarta }\end{array}$ \\
\hline 5 & Masjid Luar Batang, & $\begin{array}{l}\text { DKI Jakarta, } \\
\text { North Jakarta }\end{array}$ \\
\hline 6 & Cut Meutia Mosque & $\begin{array}{l}\text { DKI Jakarta, } \\
\text { Central Jakarta }\end{array}$ \\
\hline 7 & Al-Anshor Mosque & DKI Jakarta \\
\hline 8 & Al-Azhar Grand Mosque & $\begin{array}{l}\text { DKI Jakarta, } \\
\text { South Jakarta }\end{array}$ \\
\hline 9 & Al-Makmur Cikini Mosque & $\begin{array}{l}\text { DKI Jakarta, } \\
\text { Central Jakarta }\end{array}$ \\
\hline 10 & Jami al-Barkah Mosque & $\begin{array}{l}\text { DKI Jakarta, } \\
\text { South Jakarta }\end{array}$ \\
\hline
\end{tabular}

Local cultural heritage can be in the form of physical culture (real, such as sites, historical places, ancient buildings, statues, past cultural values such as traditions, folk tales and legends, mother tongue, oral history, creative groups such as dance, performances) and others (intangible) [10]. The research data explains that students are very interested in learning cultural heritage themes in learning local history (See Figure 1). 


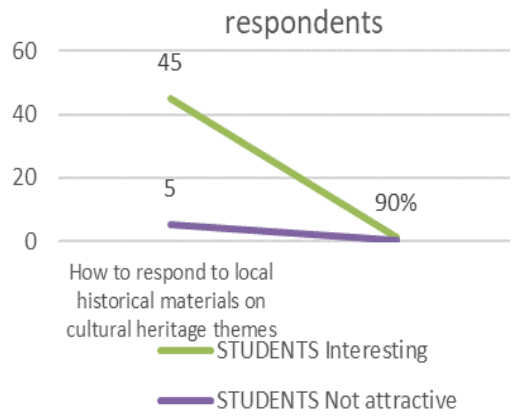

Figure 1 Responses to Cultural Heritage Themes

As many as $90 \%$ of respondents stated that local history material based on cultural heritage is very interesting to be presented in the lesson. The study of local history has succeeded in providing additional knowledge about Indonesian history in the past. Students are triggered to look for literature related to the cultural heritage presented, which triggers research on the cultural heritage material presented. Interest in the theme of cultural heritage helps the government a lot in terms of supervision and maintenance of vandalism [11].

To facilitate and improve literacy culture, it is necessary to conduct a digital mapping process of cultural heritage in DKI Jakarta or Jabodetabek. Besides being useful for learning local history, digital processes can be used to provide information to tourists visiting DKI Jakarta and Jabodetabek.

\section{CONCLUSION}

Making digital mapping of cultural heritage, helps students in learning local history as well as can be used as a supplement to learning history. Ease of obtaining cultural heritage information can assist the government in protecting and maintaining cultural heritage from acts of vandalism. Initial information related to the data collection of cultural heritage in DKI Jakarta and Jabodetabek was stated by students to be very helpful in providing more complete historical information. The initial data obtained will then be digitally processed using ArcGIS 9.3.1

\section{REFERENCES}

[1] F. Nocca. The role of cultural heritage in sustainable development: Multidimensional indicators as decisionmaking tool. Sustainability, 9 (10) (2017) 1882. DOI : https://doi.org/10.3390/su9101882

[2] A. Belal, E. Shcherbina. Heritage in post-war period challenges and solutions. IFAC-PapersOnLine, 52 (25) (2019) 252-257. DOI : https://doi.org/10.1016/j.ifacol.2 019.12 .491
[3] A. J. Burduk, P. Stec. Council of Europe Cultural Heritage and Education Policy: Preserving identity and searching for a common core?. Revista Electrónica Interuniversitaria de formación del profesorado, 22 (1) (2019) 1-12.

[4] N. Moorhouse, M. C. Tom Dieck, T. Jung. An experiential view to children learning in museums with Augmented Reality. Museum Management and Curatorship, 34 (4) (2019) 402-418. DOI : https://doi.o $\mathrm{rg} / 10.1080 / 09647775.2019 .1578991$

[5] G.Boadu. Historical significance and the challenges of African historiography: analysis of teacher perspectives. Pedagogy, Culture \& Society, (2020) 119.. DOI : https://doi.org/10.1080/14681366.2020.1843 070

[6] A. İnci, M. Doğanay, A. Özdarendeli, O. Düzlü, A. Yildirim. Overview of zoonotic diseases in Turkey: The one health concept and future threats. Türkiye Parazitoloji Dergisi, 42 (1) (2018) 39-80. DOI : https:// doi.org/10.5152/tpd.2018.5701

[7] L. Castro-Calviño, J. Rodríguez-Medina, C. J. Gómez-Carrasco, R. López-Facal. Patrimonializarte: a heritage education program based on new technologies and local heritage. Education Sciences, 10 (7) (2020) 176. DOI : https://doi.org/10.3390/educsci10070176

[8] J. Wagner-Lawlor. Poor theory and the art of plastic pollution in Nigeria: relational aesthetics, human ecology, and "good housekeeping". Social Dynamics, 44 (2) (2018) 198-220. DOI : https://doi.org/ $10.1080 / 02533952.2018 .1481685$

[9] D. T. Raharjana, P. M. Kutanegara. Pemberdayaan Masyarakat di Kawasan Cagar Budaya. Jurnal Tata Kelola Seni, 5(1) (2019) 50-65.

[10] S. Suswandari. Local History of Jakarta and MulticulturalAttitude (Historical Local Study of Betawi Ethnic). Journal of Education, Teaching and Learning, 2 (1) (2017) 34-41.

[11] Y. Moualla, G. McPherson. Making Change towards Inclusive Societies: The Soft Power of Community Archaeology in Building Cultural Heritage in Mozan, Syria. Sustainability, 11 (17) (2019) 4670. DOI : https://doi.org/10.3390/su11174670 